\title{
Taxonomic changes in palaeotropical Xyleborini (Coleoptera, Curculionidae, Scolytinae)
}

\author{
Jiri Hulcr ${ }^{1,2}$ \\ I Department of Biology, North Carolina State University, Raleigh, NC 27695, USA 2 Institute of Entomo- \\ logy, CAS, Branisovska 31, 37005 Ceske Budejovice, Czech Republic \\ Corresponding author: Jiri Hulcr (hulcr@wisc.edu)
}

Academic editor: A.I. Cognato | Received 9 September 2010 | Accepted 31 May 2010 | Published 17 September 2010

Citation: Hulcr J (2010) Taxonomic changes in palaeotropical Xyleborini (Coleoptera, Curculionidae, Scolytinae). In: Cognato AI, Knížek M (Eds) Sixty years of discovering scolytine and platypodine diversity: A tribute to Stephen L. Wood. ZooKeys 56: 105-119. doi: 10.3897/zookeys.59.520

\begin{abstract}
Following the recent reclassification of the Palaeotropic xyleborine genera (Hulcr \& Cognato 2010), additional species are transferred to correct genera or synonymized based on analysis of their morphological characters. The following species are given new combinations: Debus amphicranoides (Hagedorn), comb. n., Debus birmanus (Eggers, 1930), comb. n., Debus dolosus (Blandford, 1896), comb. n., Debus eximius (Schedl, 1970), comb. n., Debus interponens (Schedl, 1954), comb. n., Debus robustipennis (Schedl, 1954), comb. n., Debus spinatus (Eggers, 1923), comb. n., Microperus alpha (Beeson, 1929), comb. n., Microperus corporaali (Eggers), comb. n., Microperus eucalyptica (Schedl, 1938), comb. n., Microperus nugax (Schedl, 1939), comb. n., Pseudowebbia percorthylus (Schedl, 1935), comb. n., Truncaudum circumcinctus (Schedl, 1941), comb. n.

The following species are synonymized: Arixyleborus hirtipennis (Eggers), syn. n., with Arixyleborus puberulus (Blandford); Coptoborus palmeri (Hopkins), syn. n., with Debus emarginatus (Eichhoff); Coptoborus terminaliae (Hopkins), syn. n., with Debus emarginatus (Eichhoff); Cyclorhipidion polyodon (Eggers), syn. n., with Truncaudum agnatum (Eggers); Euwallacea artelaevis (Schedl), syn. n., with Planiculus bicolor (Blandford); Xyleborinus perminutissimus (Schedl), syn. n., with Xyleborinus perpusillus (Eggers); Xyleborus exesus Blandford, syn. n., with Debus emarginatus (Eichhoff); Xyleborus fulvulus (Schedl), syn. n., with Microperus corporaali (Eggers); Xyleborus marginicollis (Schedl), syn. n., with Diuncus justus (Schedl); Xyleborus shoreae Stebbing, syn. n., with Debus fallax (Eichhoff).

The following species are given new status: Streptocranus superbus (Schedl, 1951), restored name; Webbia divisus Browne, 1972, restored name; Webbia penicillatus (Hagedorn, 1910), restored name. Genus Taphrodasus Wood (1980) is declared not valid.
\end{abstract}

Copyright Jiri Hulcr. This is an open access article distributed under the terms of the Creative Commons Attribution License, which permits unrestricted use, distribution, and reproduction in any medium, provided the original author and source are credited. 


\section{Keywords}

ambrosia beetles, Debus, Microperus, reclassification

\section{Introduction}

Xyleborini are one the most species-rich groups of scolytine beetles, and one which produced many invasive pests. In spite of the economic concern, xyleborine beetles have received comparatively little attention by taxonomists. S. L. Wood (1989) made the first major attempt to organize the many hundreds of described species into a generic classification. This classification was subsequently adopted in the most comprehensive treatise on scolytine taxonomy, the Catalog of Scolytidae and Platypodidae (Wood and Bright 1992, Bright and Skidmore 1996, 2002, also on-line at: http:// www.scolytid.msu.edu). This concept was later refined using morphological cladistics (Hulcr et al. 2007a, Hulcr and Cognato, 2009), and currently summarized by AlonzoZarazaga and Lyal (2009). Hulcr and Cognato (in press) provided further rearrangements of Palaearctic and Palaeotropical Xyleborini classification using a combination of morphological and molecular approaches. This work augments the latest classification with a series of transfers and synonyms. Majority of the species treated here occur in SE Asia or Melanesia.

\section{List of abbreviations}

BMNH Natural History Museum, London

FRI Forestry Research Institute, Dehra Dun, India

MCG Museo Civico Genova, Genova

MNB Museum fur Naturkunde der Humboldt University, Berlin, Germany

MSUC Michigan State University Arthropod Collection, East Lansing, MI, USA

NHMW Natürhistorisches Museum, Wien, Austria

RAB Roger A. Beaver's private collection, Chiang Mai, Thailand

SMTD Staatliches Museum fur Tierkunde, Dresden, Germany

UCD Bohart Museum, University of California-Davis, CA, USA

USNM United States National Museum, Smithsonian Institution, Washington, D.C., USA.

\section{Taxonomic treatment}

\section{Arixyleborus puberulus (Blandford)}

Xyleborus puberulus (Blandford, 1896)

Xyleborus hirtipennis Eggers, 1940, syn. n. 
Arixyleborus hirtipennis (Eggers): Browne, 1955, syn. n.

Specimens examined. Indonesia, Java (X. hirtipennis, lectotype, USNM); Sarawak, Malaysia (X. puberulus, holotype, BMNH).

Comments. Lectotype of Arixyleborus hirtipennis bears all essential features of $A$. puberulus, only the declivital rugosities more organized into rows, shining area of elytra smaller, less clearly distinguished from rugose area. These are exceptionally plastic in $A$. puberulus, $A$. hirtipennis represents small deviation in the large range of variation of declivital surface in $A$. puberulus.

\section{Diuncus justus (Schedl)}

Xyleborus justus Schedl, 1931

Diucus justus (Schedl): Hulcr \& Cognato, 2009

Xyleborus marginicollis (Schedl, 1936b), syn. n.

Specimens examined. Indonesia, Java, Buitenzorg (D. justus, holotype, NHMW); Philippines, Luzon, (X. marginicollis, holotype, NHMW).

Length. $1.5 \mathrm{~mm}$.

Comments. Type specimen of $X$. marginicollis Schedl represents one end of a continuum of variation in D.justus: short $(1.5 \mathrm{~mm}$ ) but robust (most representatives of $D$. justus slightly longer and more slender). Diagnostic characters identical: surface of declivity devoid of vestiture, no elytral denticles, smooth impression across interstriae 2 and 3 (very shallow).

\section{Debus amphicranoides (Hagedorn), comb. n.}

Xyleborus amphicranoides Hagedorn, 1908

Specimens examined. Malaysia, Sabah, Danum Valley (2, R.A. Beaver det., MSUC); Sumatra (USNM).

Comments. Prolonged large representative of Debus. Elytral declivity deeply excavated, edge of declivity with two pairs of long teeth, but only few tubercles. Declivital surface smooth.

Debus amphicranoides (Hagedorn) possibly senior synonym of the following (NHMW): Debus birmanus (Eggers), Debus cyclopus (Schedl), Debus interponens (Schedl), Debus robustipennins (Schedl). D. birmanus identical except slightly larger, with slightly longer declivital posterolateral processes, much smaller upper tooth on declivity. $D$. interponens similar except lacks constricted declivity and has shorter posterolateral declivital processes. Schedl (1954) considered D. (as Xyleborus) interponens possible altitudinal variation of $X$. robustipennins; the two essentially identical, origi- 
nated from different elevations. Debus cyclopus similar except narrower elytral apical emargination. Debus robustipennis larger. Schedl (1954) mentioned that it only differed from $D$. amphicranoides in minor differences in declivital teeth shape.

\section{Debus birmanus (Eggers), comb. $\mathrm{n}$.}

Xyleborus birmanus Eggers, 1930

Specimens examined. Malaysia, Burma (2 indiv., BMNH).

Comments. Very similar to D. amphicranoides, possibly a synonym. Holotype at FRI not available.

\section{Debus dolosus (Blandford), comb. $\mathrm{n}$.}

Xyleborus dolosus Blandford, 1896

Specimens examined. Malaysia, Sarawak (holotype, BMNH); Malaysia, Sabah, Danum Valley (9 indiv., Hulcr det., MSUC.).

Diagnosis. Elytral declivity slightly with much higher number of declivital tubercles than other Debus. Declivity flat, not excavated, not emarginate at apex. Depth of emargination varies. Similar to Debus pumilus, but uniformly brown, with more and larger tubercles on the declivity. Significant intraspecific size variation.

Comments. Elytral declivity superficially different from other Debus spp, but its structure homologous. Few small or large tubercles in the interstriae 1 (usually 3 pairs), displaced by broadened interstriae 1 and positioned on first striae or on interstriae 2 . Strial punctures greatly reduced on declivity, difficult to follow as interstria 1 broad, displacing other striae. No tubercles originating on second striae. Smaller tubercles on striae 3 and beyond, creating tuberculated area surrounding declivity. Other characters shared with Debus spp.: extended pronotal disc, triangular protibiae with large and long but sparse denticles $(<7)$, inflated prosternal posterocoxal process, antennal club shape.

Xyleborus persimilis (Eggers) and D. dolosus (Blandford) probably synonyms. $X$. persimilis (lectotype, USNM) with slightly broader, more excavated declivity. Browne (1961) suggested that $X$. subdolosus is only a local variety of $D$. dolosus.

\section{Debus eximius (Schedl), comb. n.}

Xyleborus eximius Schedl, 1970

Specimens examined. Indonesia, Kalimantan (2, holotype \& allotype, NSMT); Indonesia, Kalimantan (2 paratypes, NHMW). 
Comments. Elytral apex not emarginate, but all other diagnostic characters of Debus present: elongated pronotal disc, broad antennal club type 2, triangular protibiae, flat elytral declivity with tubercles on elevated lateral sulcus (appears as if formed by interstriae 2 through 4 ).

\section{Debus fallax (Eichhoff)}

Xyleborus fallax Eichhoff, 1878

Debus fallax (Eichhoff): Hulcr \& Cognato, 2010

Xyleborus shoreae Stebbing, 1909, syn. n.

(complete taxonomic history in Wood and Bright, 1992)

Specimens examined. $X$. shoreae: India, Kumaon, (2), Beeson det., BMNH); Malaysia, Kedah, (two labels: X. shoreae, Browne det., X. fallax, Schedl det., BMNH); Thailand, Pong Yaeng N. P., (Beaver det.); Borneo (Schedl det., BMNH); D. fallax: Malaysia, Sabah, Danum Valley (Hulcr det.); Malaysia, Sabah, Danum Valley (51, Hulcr det.); New Guinea, Morobe Province, Bulolo (Jordal det.); New Guinea (BBM, 5 indiv.); Sulawesi (Browne det., BMNH); Thailand, Pong Yaeng N. P. (2, Hulcr det.); PNG, Madang Prov. (36), Oro Prov. (66), West Sepik (123) (Hulcr coll, det.); Philippines, Luzon, Mt. Makiling (X. amphicranulus Egg. holotype, X. fallax syn., SMTD).

Comments. Holotype of $X$. shoreae in FRI, inaccessible, non-type specimens identified by several authorities available. Location of $X$. fallax holotype unclear. Wood and Bright (1992) indicated IRSNB as holotype depository, however museum personell reports that holotype has never been deposited there. X. shoreae is a variant of $D$. fallax (Eichhoff), declivital emargination shallower than in most $D$. fallax. All other characters identical to $D$. fallax: color uniformly brown to bicolored (light brown to orange pronotum), elytral denticles all small except the denticle in the middle of declivital face, which is slightly longer than others; declivity surface shining, most specimens with remnants of strial punctures, size $2.6-3.0 \mathrm{~mm}$. Declivity emargination depth intermediate between $D$. fallax and D. emarginatus, most other characters (size, coloration, flat posterolateral processes) shared with D. fallax. Maiti and Saha (2004) had access to holotype, redescription and illustration fits $D$. fallax. Stebbing not consistent in distinguishing $X$. shoreae from $X$. fallax, assigned similar specimens to either species (Maiti and Saha 2004).

Biology and distribution: Reported from India and Thailand, and by Browne (1983) as imported from PNG to Japan. Despite the name "shoreae", the species is a broad generalist (Wood and Bright, 1992). 
Debus interponens (Schedl), comb. $\mathbf{n}$.

Xyleborus interponens Schedl, 1954

Specimens examined. Malaysia, Sarawak, Mt. Penrissen, 4500 ft. (lectotype, NHMW).

Comments. All diagnostic features of genus Debus present, including antennal club form, prolonged pronotum, emarginate declivity. Similar to $D$. amphicranoides (Hagedorn), but with less constricted declivity and longer posterolateral declivital processes. Schedl (1954) considered D. interponens altitudinal variant of D. robustipennins, the two are allegedly identical, only differing by their origins from different elevations.

Debus robustipennis (Schedl), comb. $\mathrm{n}$.

Xyleborus robustipennis Schedl, 1954

Specimens examined. Indonesia, Borneo (lectotype, NHMW).

Comments. All diagnostic features of Debus present, including antennal club form, prolonged pronotum, emarginate declivity.

Lectotype of $X$. robustipennis Schedl very similar to non-type specimens of Debus amphicranoides (Hagedorn) in USNM, only slightly larger. Schedl (1954) indicated that $X$. robustipennis differs from $X$. amphicranoides very little, merely by shallower and wider declivital emargination, having the lateral declivital costa between teeth 1 and 2 more elevated, and lateral declivital process shorter. Type of D. amphicranoides not available, thus synonymy could not be confirmed.

\section{Debus spinatus (Eggers), comb. n.}

Xyleborus spinatus Eggers, 1923

Specimens examined. Malaysia (BMNH); Malaysia, Sabah, Danum Valley (3, Hulcr det.).

Diagnosis. An "elegant" form of D. fallax. Longer, smooth declivity, shallowly emarginate, no tubercles or granules on declivital sides except two pairs of slender teeth, one long, one short. Declivity shagreen when dry.

\section{Debus emarginatus (Eichhoff)}

Xyleborus emarginatus Eichhoff, 1878

Debus emarginatus (Eichhoff): Hulcr \& Cognato, 2010

Xyleborus terminaliea Hopkins, 1915, syn. n. 
Coptoborus terminaliae (Hopkins) Wood and Bright, 1992, syn. n.

Xyleborus exesus Blandford, 1894, syn. $\mathbf{n}$.

Xyleborus palmeri Hopkins, 1915, syn. n.

Coptoborus palmeri (Hopkins): Wood \& Bright, 1992, syn. n.

(complete taxonomic history in Wood and Bright, 1992)

Specimens examined. X. terminaliae: Philippines, Pagbilao (holotype, USNM). X. exesus: Japan, (holotype, BMNH). D. emarginatus: Indonesia, Sumatra, Bandar Baroe (homotype, compared to type by Eggers, NHMW); Indonesia, Java, Bandjar (homotype, compared to type by Eggers, NHMW, 2 indiv.); Philippines, Laguna, Pangil (homotype, NHMW); Malaysia, Sabah, Danum Valley (17 indiv., Hulcr det., MSUC); New Guinea (BBM, 20 indiv.); New Guinea, Ambunti (4, BBM); New Guinea (FICB); New Guinea, Gulf Province, Ivimka (UCD); Thailand, Pong Yaeng N. P. (Hulcr det., MSUC); PNG, Madang Prov. (79, Hulcr coll.).

Comments. Holotypes of $X$. exesus Blandford, X. palmeri Hopkins, and X. terminaliae Hopkins share all diagnostic characters with homotype and large series of nontypes of Debus emarginatus (Eichhoff). X. exesus: declivity with slightly less steep slope, less pronounced lateral tubercles (granules), dominant tubercle in middle of lateral sulcus slightly longer. Schedl (1973e) suggested synonymy of non-New Guinean X. emarginatus Schedl with $X$. exesus Blandford, based on shared shallow declivital emargination. Holotype of $X$. exesus damaged, missing elytron, fits range of $D$. emarginatus variation. $X$. palmeri Hopkins is larger variant of typical D. emarginatus.

\section{Microperus alpha (Beeson), comb. n.}

Xyleborus alpha Beeson, 1929

Coptodryas alpha (Beeson) Wood \& Bright, 1992

Specimens examined. India, Sunderbans Div. (holotype, BMNH).

Comments. All diagnostic features of Microperus present: small size, elytral punctures aligned in striae, and prolonged body shape (Hulcr and Cognato in press). Similar to Microperus pometianus, but slightly longer, with distinctly elevated and long declivital costa.

\section{Microperus corporaali (Eggers), comb. $\mathrm{n}$.}

Xyleborus corporaali (Eggers, 1923)

Coptodryas corporaali (Eggers): Wood \& Bright, 1992

Xyleborus fulvulus (Schedl, 1942b), syn. n.

Xyleborus fulvus (Schedl, 1939): X. fulvulus (Schedl, 1942), preoccupied (Xyleborus fulvus Murayama 1936), syn. n. 
Specimens examined. M. corporaali: Indonesia, Kotangan an der Ostkusgte (lectotype, USNM); X. fulvulus: Indonesia, Sumatra (paratype, USNM).

Comments. X. fulvulus identical to Microperus corporaali (identical antennae, body shape, declivital surface and shape, posterolateral declivital costa, declivital vestiture as one row of erect setae per intrestria, backward-bent setae in strial punctures). Paratype not mentioned by Anderson and Anderson (1971).

Microperus eucalyptica (Schedl), comb. n.

Xyleborus eucalyptica Schedl, 1938

Coptodryas eucalyptica (Schedl): Wood \& Bright, 1992

Specimens examined. Australia, Queensland, Geagana (lectotype, NHMW).

Comments. All diagnostic features of Microperus present (elytral mycangia, absence of scutellum, small size, prolonged body shape, abundant vestiture). Similar to $M$. intermedius, but substantially longer, elytra often bicolored, usually without convexity on elytral disc.

Microperus nugax (Schedl), comb. $\mathbf{n}$.

Xyleborus nugax Schedl, 1939

Coptodryas nugax (Schedl): Wood \& Bright, 1992

Specimens examined. Malaysia, Selangor (lectotype, BMNH); Malaysia, Selangor (Schedl det., BMNH); Malaysia, Sabah, Danum Valley, (13, Hulcr det., MSUC).

Diagnosis. Very similar to Microperus diversicolor (e.g., antennal club type 3), except pronotum bright yellow with brown patch, elytra black, declivity commencing closer to elytral base, declivital interstriae covered with many small sharp hooks (similar as in M. parva, but larger). Characteristic elytral disc: anterior portion inflated, convex, boundary between elytral disc and declivity slightly concave, impressed.

Comments. Schedl (1979) designated lectotype in NHMW, another unspecified "type" resides in BMNH. Possibly synonymous with Coptodryas undulata (Sampson) (as X. leprosulus Schedl, syn. Wood, 1989) (Schedl, 1939).

Biology. Creates irregularly branching galleries with transverse brood chambers (Beaver \& Browne 1978).

\section{Planiculus bicolor (Blandford)}

Xyleborus bicolor Blandford, 1894

Euwallacea bicolor (Blandford): Wood \& Bright, 1992 
Planiculus bicolor (Blandford): Hulcr \& Cognato, 2010

Xyleborus artelaevis (Schedl, 1942a), syn. $\mathrm{n}$.

Euwallacea artelaevis (Schedl): Beaver, 1998, syn. n.

Xyleborus rameus Schedl, 1940

Xyleborus bicolor (Schedl): Kalshoven, 1959

Specimens examined. $X$ artelaevis: Malaysia, Perak, (holotype, NHMW); New Guinea, Gulf Province, Ivimka, (R.A. Beaver det., UCD); Indonesia, Sulawesi (R. A. Beaver det., BMNH). P. bicolor: Nagasaki, Japan (syntype, BMNH); Fiji, Namosi (X. rameus (syn. P. bicolor) Schedl det., BMNH).

Comments. Holotype of $X$. artelaevis virtually identical to Planiculus bicolor (Blandford), except first segment of antennal club more convex. All other characters identical, including uniform granules in declivital interstriae 1, 2, and 3 (same size granules in interstriae 1-3 characteristic for P. bicolor). X. artelaevis holotype deteriorated, missing or damaged body parts including antenne.

\section{Pseudowebbia percorthylus (Schedl), comb. n.}

Xyleborus percorthylus Schedl, 1935

Taphrodasus percorthylus (Schedl): Wood, 1980

Specimens examined. Malaysia, Peninsula (holotype, NHMW).

Comments. Diagnostic characters of Pseudowebbia: regular type of pronotum (not extremely prolonged and flat as in Webbia), circular antennal club (not broadened), triangular to broadly rounded protibia (not thin and sickle-like as in Webbia). Elytral declivity deeply excavated, surrounded by highly elevated circumdeclivital costa with no teeth.

Type species of Taphrodasus Wood, 1980. Morphological limits of Taphrodasus never specified. Characters listed by Wood (1980) are either autapomorphic to T. percorthylus, or present in other genera, mostly Webbia. Taphrodasus not a valid genus, see below.

\section{Streptocranus superbus (Schedl), stat. n.: restored name}

Xyleborus superbus Schedl, 1951

Coptoborus superbus (Schedl): Wood \& Bright, 1992

Xyleborus superbulus Schedl, 1958a, unnecessary replacement name

Coptoborus superbulus (Schedl, 1958a): Wood \& Bright, 1992, unnecessary replacement name

Specimens examined. Indonesia, Java, Buitenzorg (holotype, NHMW). 
Comments. Xyleborus superbus Schedl (1951) preoccupied by Xyleborus superbus Schedl (1942c). Renamed X. superbulus (Schedl, 1958a). X. superbus Schedl (1942c) later placed in Coptoborus (Wood and Bright 1992). Replacement name unnecessary, original name S. superbus (Schedl, 1951) restored.

\section{Genus Taphrodasus Wood, stat. n.: invalid genus}

Taphrodasus Wood (1980), monotypic, type species Taphrodasus percorthylus (Schedl, 1935): Wood, 1980. Later included in Taphrodasus: Webbia divisus Browne (1972), Xyleborus penicillatus Hagedorn (1910), Xyleborus cuspidus Schedl (1975). T. percorthylus transferred to Pseudowebbia (Hulcr and Cognato, this volume); T. divisus and T. penicillatus restored in Webbia (Hulcr and Cognato, this volume), T. cuspidus not related to any of the other three species (Hulcr and Cognato, in prep.).

\section{Truncaudum agnatum (Eggers)}

Xyleborus agnatus Eggers, 1923

Cyclorhipidion agnatum (Eggers): Wood \& Bright, 1992

Truncaudum agnatum (Eggers): Hulcr \& Cognato, 2010

Xyleborus polyodon (Eggers, 1923), syn. n.

Cyclorhipidion polyodon (Eggers, 1923): Wood \& Bright, 1992, syn. n.

(complete taxonomic history in Wood and Bright, 1992)

Specimens examined. T. agnatum: New Guinea, Hatam (cotype, MCG). X. polyodon: Philippines, Luzon, Mt. Makiling; (unspecified "type”, SMTD).

Comments. Type of $X$. polyodon similar to T. agnatum, except tubercles on and around declivity larger, pointed. Tubercles in homologous position. Eggers's unspecified "type" in SMTD from the same collection series as lectotype at USNM (Anderson \& Andreson, 1971).

Truncaudum circumcinctus (Schedl), comb. $\mathbf{n}$.

Premnobius circumcinctus Schedl, 1941

Premnobius circumcinctus (Schedl): Wood \& Bright, 1992

Xyleborus circumcinctus (Schedl): Schedl, 1962b

Specimens examined. Uganda (P. circumcinctus, holotype, NHMW).

Comments. The only known African Truncaudum. Truncaudum synapomorphies: impressed submentum, antennal club type 1, curved outer edge of protibiae, complete denticulated circumdeclivital costa. Very similar to Truncaudum impexus [(Schedl): 
Hulcr and Cognato (in press)], except declivity slightly convex (mostly flat in Truncaudum spp.), antenna type 1, several adjacent denticles on each stria on the upper edge of circumdeclivital costa (mostly a single flat tubercle in Truncaudum spp.). Otherwise remarkably similar to Asian relatives. Length: $2.8 \mathrm{~mm}$.

Described as Premnobius by Schedl (1941), later treated as Xyleborus (Schedl, 1962b), but combination never offically published.

\section{Webbia divisus Browne, stat. n.: restored name}

Webbia divisus Browne (1972)

Taphrodasus divisus (Browne): Wood \& Bright, 1992

Specimens examined. Malaysia, Perak (holotype, BMNH).

Comments. Transferred to Taphrodasus (Wood and Bright, 1992) without discussion of characters. Webbia synapomorphies: dorsal aspect of pronotum long and quadrangular, pronotal disc long and flat, frontal slope of pronotum short, scutellum suppressed, costate and setose elytral bases. Differs from most Webbia spp. by densely pubescent and excavated declivity and elongated body shape. Length: $2.4 \mathrm{~mm}$. Characters shared with Pseudowebbia percorthylus [(Schedl, 1935): Hulcr and Cognato, this volume] (type species of Taphrodasus) limited to excavated declivity with dense setae, genus-level characters different.

Webbia penicillatus (Hagedorn), stat. n.: restored name

Xyleborus penicillatus Hagedorn 1910

Prowebbia penicillatus (Hagedorn): Browne 1963

Webbia penicillatus (Hagedorn): Bright 2000

Taphrodasus penicillatus (Hagedorn): Wood \& Bright, 1992

Specimens examined. Malaysia, N.S. Triang (homotype, NHMW); Malaysia, Perak (BMNH); Malaysia, Borneo (BMNH).

Comments. Type in Hamburg museum lost (Wood and Bright 1992). Most features characteristic of Webbia (elongated pronotum, suppressed scutellum), unrelated to type species of Taphrodasus: Pseudowebbia percorthylus ((Schedl, 1935): Hulcr \& Cognato, this volume). Similar to $W$. divisus, except declivity with long, dense, erect setae, not scales.

\section{Xyleborinus perpusillus (Eggers)}


Xyleborinus perpusillus (Eggers): Wood \& Bright, 1992

Xyleborinus perminutissimus (Schedl, 1934) syn. $\mathbf{n}$.

Specimens examined. X. perminutissimus: Indonesia, Java, Mt. Gede (lectotype, NHMW). X. perpusillus: Indonesia, Sumatra (holotype, USNM); Malaysia, Sarawak, Gunung Buda (R.A. Beaver det., MSUC); Malaysia, Sabah, Danum Vallery $(29$ indiv., Hulcr coll.); New Guinea, Oro Province, Kanga (5 indiv, Hulcr coll.).

Comments. Lectotype of Xyleborinus perminutissimus (Schedl, 1934d) virtually identical to holotype of Xyleborinus perpusillus (Eggers). Slightly smaller tubercles in some declivital interstriae, but pattern identical: tubercles missing from interstriae 2 .

\section{Acknowledgements}

My utmost thanks belong to Dr. S. L. Wood for creating a classification of scolytine beetles upon which all current and future bark beetle taxonomists can build. I thank Dr. A. I. Cognato for helping organize this series of publications, and for his support of my work. The work was sponsored by USDA-APHIS grant, National Science Foundation (PEET DEB-0328920), National Geographic Society (7922-05), and the Ministry of Education fo the Czech Republic(MSM 60076605801). I am indebted to curators of the museums who readily loaned specimens for examination: M. Barclay (BMNH), R. Poggi (MCG), J. Frisch and J. Willers (MNB), H. Schoenmann (NHMW), and O. Jaeger (SMTD). S. Heydon and L. Kimsey kindly supported my extended work in the UCD collection. I thank R. A. Beaver for specimens and unceasing advice.

\section{References}

Alonso-Zarazaga M, Lyal CHC (2009) A catalogue of family and genus group names in Scolytinae and Platypodinae with nomenclatural remarks (Coleoptera: Curculionidae). Zootaxa 2258: $1-134$.

Anderson DM, Anderson WH (1971) Type specimens in the Hans Eggers collection of scolytid beetles (Coleoptera). Smithsonian Contributions to Zoology 94: 1-38.

Atkinson TH, Rabaglia RJ, Bright, DE (1990) Newly detected exotic species of Xyleborus (Scolytidae) in eastern North America, with a revised key to species. Canadian Entomologist 122: 93-104.

Beaver RA (1998) New synonymy, new combinations and taxonomic notes on Scolytidae and Platypodidae (Insecta: Coleoptera). Annalen des Naturhistorischen Museums in Wien 100B: 179-192.

Beeson CFC (1929) Platypodidae and Scolytidae. British Museum (Natural History). Insects of Samoa, Part 4, Coleoptera, fascicle 4: 217-248.

Blandford WFH (1894) The Rhynchophorous Coleoptera of Japan. Part III. Scolytidae. Entomological Society of London, Transactions 1894: 53-141. 
Blandford WFH (1896) Descriptions of new Scolytidae from the Indo-Malayan and AustroMalayan regions. Entomological Society of London, Transactions 1896: 191-228.

Bright DE (2000) Scolytidae (Coleoptera) of Gunung Mulu National Park, Sarawak, Malaysia, with ecological notes and descriptions of six new species. Serangga 5: 41-85.

Bright DE, Skidmore RE (1997) A Catalog of Scolytidae and Platypodidae (Coleoptera), Supplement 1 (1990-1994). NRC Research Press, 368 pp.

Bright DE, Skidmore RE (2002) A Catalog of Scolytidae and Platypodidae (Coleoptera): Supplement 2. NRC Research Press 2002, 523 pp.

Browne FG (1955) Synonymy and descriptions of some oriental Scolytidae and Platypodidae (Coleoptera). Sarawak Museum Journal 6: 343-373.

Browne FG (1961) The biology of Malayan Scolytidae and Platypodidae. Malayan Forest Records 22: 255.

Browne FG (1963) Taxonomic notes on Scolytidae (Coleoptera). Entomologische Berichten 23: 53-59.

Browne FG (1972) Some oriental Scolytidae and Platypodidae (Coleoptera). Oriental Insects 6: 19-32.

Browne FG (1983) Bark beetles and ambrosia beetles (Coleoptera, Scolytidae and Platypodidae) intercepted at Japanese ports, with descriptions of new species, VII. Kontyu 51: $554-572$.

Eggers H (1923) Neue indomalayische Borkenkafer (Ipidae). Zoologische Mededelingen 7: $129-220$.

Eggers H (1927) Neue indomalayische Borkenkafer (Ipidae). 1 Nachtrag. Treubia 9: 390-408. Eggers H (1930) Neue Xyleborus-Arten (Col. Scolytidae) aus Indien. India Forest Records Entomology.

Eggers H (1940) Neue indomolayische Borkenkafer (Ipidae). III. Nachrag (Forstsetzung). Tijdschrift voor Entomologie 83: 132-154.

Eichhoff WJ (1868) Neue amerikanische Borkenkafer-Gattungen und Arten. Zweites Stuck. Berliner Entomologische Zeitschrift.

Eichhoff WJ (1875) Felicien Chapuis et W. Eichhoff, Scolytides recueillis au Japan par M. C. Lewis. Societe Entomologique de Belgique, Annales 18: 195-203.

Eichhoff WJ (1878) Ratio, descriptio, emendatio eorum Tomicinorum qui sunt in Dr. Medin. Chapuisi et autoris ipsius collectionilbus et quos praeterea recognovit. Societe Entomologique de Liege, Memoires 81, 532 pp.

Hagedorn JM (1908) Diagnosen bisher umbeschriebener Borkenkafer. Deutsche Entomologische Zeitschrift 1908: 369-382.

Hagedorn JM (1910) Diagnosen bisher unbeschriebener Borkenkafer (Col.). Deutsche Entomologische Zeitschrift Ser. 2: 1-13.

Hagedorn JM (1912) Borkenkafer (Ipidae) Welche in Kautschukbaumen Leben. Revue Zoologique Africaine 1: 336-346.

Hopkins AD (1915) Classification of the Cryphalinae with descriptions of new genera and species. USDA Report 99: 1-75.

Hulcr J, Cognato AI (2009) Three new genera of Oriental Xyleborina (Coleoptea: Curculionidae: Scolytinae). Zootaxa: 2204: 19-36. 
Hulcr J, Cognato AI (in press) New genera of Palaeotropical Xyleborini (Coleoptera: Curculionidae: Scolytinae) based on congruence between morphological and molecular characters. Zootaxa.

Kalshoven LGE (1959) Studies on the biology of Indonesian Scolytoidea 4. Data on the habits of Scolytidea, Second part. Tijdschrift voor Entomologie 102: 135-173.

Maiti PK, Saha N (2004) Scolytidae: Coleoptera (Bark and Ambrosia Beetles) Volume 1, Part 1, Introduction and tribe Xyleborini. Zoological Survey of India: Kolkata.

Motschulsky V (1863) Essai d'un catalogue des insectes de l'ile Ceylon. Moskov Obschch Isp. Prirody Biol. Biul (Bulletin de la Societe Imperiale des Naturalistes de Moscou) 36: 509517.

Murayama JJ (1936) Notes sur les Scolytides (Coleopteres) de Honshu et Kiushu, Japon. Tenthreeo 1: 121-149.

Schedl KE (1931) Notes on the genus Xyleborus Eichh. Annals and Magazine of Natural History 8: 339-347.

Schedl KE (1934) Neue Indomalayische Scolytidae. II. Beitrag. Entomologische Berichten 9: 84-92.

Schedl KE (1935) New bark-beetles and ambrosia-beetles (Col.). Stylops 4: 270-273.

Schedl KE (1936a) Notes on Malayan Scolytidae and Platypodidae and descriptions of some new species. Journal of the Federated Malay States Museums 18: 1-18.

Schedl KE (1936b) Scolytidae and Platypodidae: Fauna Philippinensis, IV. Philippine Journal of Science 60: 59-67.

Schedl KE (1938) Scolytidae and Platypodidae. Contribution, 49. New species from Australia and the Fijii Islands with some revisional notes. Royal Society of South Australia, Transactions 62: 34-52.

Schedl KE (1939) Malaysian Scolytidae and Platypodidae (IV). 57th contribution. Journal of the Federated Malay States Museums 18: 327-364.

Schedl KE (1941) Neue afrikanische Gattungen und Arten. 72 Beitrag. Revue de Zoologie et de Botanique Africaines 34: 379-424.

Schedl KE (1942a) Forschungberiche zur Scolytoiden-Fauna der Malayischen Halbinsel, V. 80 Beitrag. Kolonialforstliche Mitteilungen 5: 169-218.

Schedl KE (1942b) Neue Scolytidae aus Java. 76 Beitrag. Tijdschrift voor Entomologie 85: $1-49$.

Schedl KE (1942c) Interessante und neue Scolytiden und Platypodiden aus der australischen Region. 79 Beitrag. Mitteilungen der Munchener Entomologische Gesellschaft 32: 162201.

Schedl KE (1951) Fauna Indomalayaensis, I. 91. Beitrag. Tijdschrift voor Entomologie

Schedl KE (1954) Scolytoidea (beetles) from Borneo. Sarawak Museum Journal 6: 154-163.

Schedl KE (1958a) Zur Synonymie der Borkenkafer, II. 159 Beitrag. Tijdschrift voor Entomologie 101: 141-155.

Schedl KE (1958b). A few new African Scolytidae in the British Museum, 168. Contribution. Annals and Magazine of Natural History 13: 557-560.

Schedl KE (1960) Synonymies of bark beetles (Scolytidae), IV. 174 Contribution. Coleopterists' Bulletin 145: 12. 
Schedl KE (1962a) Scolytidae und Platypodidae aus dem australisch-polyneisischen Raum 206 Beitrag. Entomologischen Arbeiten aus dem Museum G. Frey 13: 72-78.

Schedl KE (1962b) Scolytidae und Platypodidae Afrikas. Band 3. Familie Platypodidae. Revista de Entomologia de Mocambique 5: 1-594.

Schedl KE (1970) Bark beetles and pin-hole borers (Scolytidae and Platypodidae) intercepted from imported logs in Japanese ports, IV. 274 Contribution. Kontyu 38: 353-370.

Schedl KE (1979) Die Typen der Sammlung Schedl Familie Scolytidae (Coleoptera), Kataloge der wissenschaftlichen Sammlungen des naturhistorischen Museums in Wien, Entomologie 3: 21-286.

Stebbing EP (1909) On some undescribed Scolytidae of economic importance from the Indian Region, II. Indian Forest Memoirs, Forest Zoology Series 1: 13-32.

Wood SL (1975) New synonymy and new species of American bark beetles (Coleoptera: Scolytidae) Part II. Great Basin Naturalist 35: 391-401.

Wood SL (1980) New genera and new generic synonymy in Scolytidae (Coleoptera). Great Basin Naturalist 40: 89-97

Wood SL (1989) Nomenclatural changes and new species of Scolytidae (Coleoptera), part IV. Great Basin Naturalist 49: 167-185.

Wood SL, Bright DE (1992) A catalog of Scolytidae and Platypodidae (Coleoptera), Part 2: Taxonomic Index. Great Basin Naturalist Memoirs 13, 1553 pp. 
